\title{
Factor identification of higher education choice to enhance brand awareness of state university
}

\author{
Almira Puan Rachmadhani ${ }^{1, *}$, Naniek Utami Handayani ${ }^{1}$, Mochammad Agung Wibowo $^{2}$, Ratna Purwaningsih ${ }^{1}$ and Hery \\ Suliantoro ${ }^{1}$
}

${ }^{1}$ Department of Industrial Engineering, Faculty of Engineering, Diponegoro University, Indonesia

${ }^{2}$ Department of Civil Engineering, Faculty of Engineering, Diponegoro University, Indonesia

\begin{abstract}
The commercialization of higher education through the concept of Perguruan Tinggi Negeri Berbadan Hukum (PTN-BH) has led the higher competition among State University and Private University. It becomes a threat and challenge faced by State University in recruiting new students. A clearer understanding of why and how students choose universities is needed to develop the brand awareness enhancement strategies of State University. This paper aims to identify the factors that influence student's decision of university choice, without regarding the individual aspects. The Deplhi technique is used at the stage of information gathering, in which four experts from higher education were being interviewed. The combination of HEdPERF dimensions and brand awareness indicators were used to develop the variables. The pilot study done through the sample of 1st-year undergraduate students enrolled in the Top 8 State Universities in Indonesia for the validation test using SPSS 16.0. This findings result that there are six factors in choosing higher education, including academics, facilities, campus life, reputation, industry linkage and access. The test and evaluations result that from 28 items proposed, there are 23 items that can be considered as the student's decision in their choice of State University.
\end{abstract}

\section{Introduction}

Higher education in Indonesia has grown rapidly, which was only demanded by 200 students in the post-World War II, now reaching 4,3 million students that spread over 83 (2.7\%) State Universities and 2987 (97.3\%) Private Universities. Although the number of Private University in Indonesia is much higher than the State University, the enthusiasts of State University continues to increase every year. In 2015, the number of prospective students that interest in State University increased 5 to 10 times.

Nowadays, the trend of business is starting to change. People are customers who will drive the company, so that the business must be obtained with the provision of understanding the needs and desires of their customers. Higher education is being driven towards commercial competition as the impact of economic forces caused by the development of global education markets and the reduction of government funds that forces them to seek other financial resources [1]. In Indonesia, based on UU No. 12 Tahun 2012, the govenrment has organized a new concept of higher education that called as Perguruan Tinggi Negeri Berbadan Hukum (PTN-BH), in which State University has more autonomy at self-regulate, or given an independency at managing three aspects of business, including finance, infrastructure and employment.

The commercialization of higher education has led the higher competition among State and Private University.
In the last decade, Private University has proven their ability in providing an educational services that conform to the needs and desires of their customers, both in the aspects of finance and infrastructure. This might become a threat and challenges that must faced by State University. They must be able to keep the loyalty of their customers up and raising awareness of their existence. State University had to increase their brand awareness, the recognition and recall of a brand and its differentiation from other brands in the field [2] that commonly measured by 4 indicators, including recall, recognition, purchase and consumption. A clearer understanding of why and how students choose higher education has to be considered as the basis in developing marketing strategies for State University [3], to make the State University become top of mind in Indonesian society.

Various studies on the impact of brand on higher education have been conducted. One of them prove that the reputation of the university becomes the main indicator which determines the uniqueness of higher education [4]. With the adoption of the concept of branding, reputation becomes more important to develop the identity of higher education institution to improve their reputation in the competitive global environment.

The purpose of this study is to identify and validate the factors that influence the student's decision about their choice of university. However, understanding the process of student decision making in choosing university is complex. Hence, this study restricted to the internal

\footnotetext{
Corresponding author: apuanr@gmail.com
} 
factors that could maintained by the university, without regarding the individual aspects.

\section{Literature review}

There are several groups of customers in higher education, such as students, employers, academic staff, government and families, with a diversity of requirements [1]. General view defines that the primary participant in educational services is the student [5]. Students form their perceptions of brand image, identity and meaning before enrolling at university, that continued during their study and even after they were graduated [6]. Also, their ability to recognize the brand of university are varies depending on its brand communication. So that, the existence of university depend on the quality of their students that will equally impacted to brand awareness.

Education is related to knowledge enhancement (teaching resources), co-curricular activities (campus life), and the industrial opportunities [7]. There are three stages in student's decision making of selecting higher education: (i) predisposition, (ii) search and (iii) choice decision [8]. Another researcher defined that higher education need to interact and impress their customer in the different way to build an organization's brand at the three touchpoints of customer experience: (i) preadmission, (ii) during the course and (iii) post-passing, that represented by every action, tactic or strategy taken to reach their customers [7]. Meanwhile, this research focus on the choice decision of higher education that related to pre-admission touchpoints.

Prestige of an university is sometimes more important that its actual quality, because it represents their perceived excellence as the guidance to the decisions of prospective students to enroll the university [9]. There are six factors affecting customers satisfaction in higher education, that called HEdPERF, namely non-academic aspects, academic aspects, reputation, access, programmes issues and understanding [1]. On the other hand, there are 7 factors of reputation in higher education, including teaching staff, course materials, facilities, administrative support, campus life, industry linkage and reputation [10].

Hence, there are six constructs developed in this research related to the existing literature that can be described as follows:

- Academics, related to the importance of offering wide ranging and reputable of academic programmes and teaching staff.

- Facilities, related to the soft and hard infrastructure that will supports students on their learning process.

- Campus life, related to the co-curricular and extracurricular activities that the campus provides to develop students' softskill besides the academic activities.

- Reputation, related to the professional image projection of higher education that impacted by the media influence, track record of alumnus and achievement of university at both national and international scope.

- Industry linkage, related to the cooperation of higher education with various national and international industries that will affect the career prospects of their students.
- Access, related to the approachability, ease of contact, availability and convenience given by the higher education.

\section{Research methods}

This research conducted using both qualitative and quantitative measures to identify and validate the factors that influence the student's decision about their choice of higher education. In particular, this study attempts to qualitatively identify the factors of student's decision in choosing higher education, and incorporate the quantitatively validation to a sample of population. A detailed description of the stages described below.

\subsection{Information gathering}

This stage involves an in-depth literature searching to identify factors that influence students in choosing their university. A total 8 carefully selected students from different universities were invited to participate in the focus groups. A set of questions was created by the researcher and participants were asked to describe various aspects related to the choice of university.

\subsection{Development of research variables}

The results of focus group interviews then generated into the draft of questionnaire, consist of 6 constructs and 28 items related to different factors in the higher education decision making. The Delphi technique used as an initial validation and the items were measured on a 2-point scale, agree and disagree, by four experts (academicians and practitioners). They were asked to give an approval and comments concerning the questionnaire.

\subsection{Pilot testing and validation}

The final questionnaire were presented in functional and dysfunctional question and measured on a five-point Likert scale that varied from $1=$ strongly disagree to $5=$ strongly agree. Data were collected by personal approach from the 1st-year undergraduate students over Top 8 State Universities in Indonesia. A total 50 students have been surveyed, $68 \%$ were female in the age of $18-20$ years old.

\section{Results and discussion}

The factors were selected based on literature regarding the customer needs and branding of higher education. The results presented in Table 1 .

\subsection{Research variables}

Academics are identified as the teaching and learning process. Reputation of the teaching staff (A1) is the educational backgrounds and achievement of the lecturers in various research and community services. Diversity of the majors (A2) are the varied and specalized majors provided at the university. Accreditation of the majors 
(A3) are the is the formal recognition from accreditation entity against the majors competency and quality.
Uniqueness of the majors (A4) are defined as the favorite and desirable majors from year to year.

Table 1. Research variables.

\begin{tabular}{|c|c|c|c|}
\hline Constructs & Items & Code & Source \\
\hline \multirow[t]{4}{*}{ Academics } & $\begin{array}{l}\text { Reputation of the } \\
\text { teaching staff }\end{array}$ & A1 & \multirow[t]{4}{*}{$\begin{array}{c}{[3],[7],} \\
{[10]}\end{array}$} \\
\hline & Diversity of the majors & $\mathrm{A} 2$ & \\
\hline & $\begin{array}{l}\text { Accreditation of the } \\
\text { majors }\end{array}$ & A3 & \\
\hline & Uniqueness of the majors & A4 & \\
\hline \multirow[t]{5}{*}{ Facilities } & Academic facilities & F1 & \multirow[t]{5}{*}[12]{} \\
\hline & Health centre & $\mathrm{F} 2$ & \\
\hline & Sports facilities & F3 & \\
\hline & Lifestyle facilitators & $\mathrm{F} 4$ & \\
\hline & Students dormitory & F5 & \\
\hline \multirow[t]{5}{*}{$\begin{array}{l}\text { Campus } \\
\text { life }\end{array}$} & Students union & $\mathrm{C} 1$ & \multirow[t]{5}{*}{$\begin{array}{l}{[10],} \\
{[12]}\end{array}$} \\
\hline & Campus events & $\mathrm{C} 2$ & \\
\hline & Co-curricular activities & $\mathrm{C} 3$ & \\
\hline & Scholarship programmes & $\mathrm{C} 4$ & \\
\hline & Internship programmes & $\mathrm{C} 5$ & \\
\hline
\end{tabular}

Facilities are related to the infrastructure provided by the university. Academic facilities (F1) are the facilities that supports the learning process, such as classrooms, libraries and laboratories. Health centre (F2) is the medical clinics provided for students. Sports facilities (F3) are the facilities that supports sports activities, such as field, sports equipment and swimming pool. Lifestyle facilitators (F4) are defined as the facilities that supports the basic needs of students, such as ATM centre and print shop. While, students dormitory (F5) is the house provided for the 1-st year or underprivileged students.

Campus life is considered as another activities provided besides the academic activities. Students union (C1) is the college organizations that accomodated the students' talents, interests and their potency undertaken in extra-curricular activities. Campus events (C2) is defined as the top events held by university as their icon and promotion to the public society. Co-curricular activities (C3) or known as Unit Kegiatan Mahasiswa (UKM) is identified as student organizations at sports and arts. Scholarship programmes (C4) are the number of financial aid given to students as the appreciation for achievement at their study. Also, internship programmes (C5) are the chance of students on experiencing as the professional worker at various companies for the short-term period.

\begin{tabular}{|c|c|c|c|}
\hline Constructs & Items & Code & Source \\
\hline \multirow[t]{8}{*}{ Reputation } & $\begin{array}{l}\text { Reputation within the } \\
\text { community }\end{array}$ & $\mathrm{R} 1$ & \multirow[t]{8}{*}{ [7], [10] } \\
\hline & $\begin{array}{c}\text { Accreditation of the } \\
\text { university }\end{array}$ & $\mathrm{R} 2$ & \\
\hline & $\begin{array}{c}\text { National rankings of the } \\
\text { university }\end{array}$ & $\mathrm{R} 3$ & \\
\hline & $\begin{array}{l}\text { International rankings of } \\
\text { the university }\end{array}$ & $\mathrm{R} 4$ & \\
\hline & Prestige of the university & $\mathrm{R} 5$ & \\
\hline & $\begin{array}{c}\text { Information about } \\
\text { university in mass media }\end{array}$ & R6 & \\
\hline & Alumni recommendation & R7 & \\
\hline & Research quality & $\mathrm{R} 8$ & \\
\hline \multirow[t]{3}{*}{$\begin{array}{l}\text { Industry } \\
\text { linkage }\end{array}$} & $\begin{array}{l}\text { National industry } \\
\text { partners }\end{array}$ & I1 & \multirow[t]{3}{*}[10]{} \\
\hline & $\begin{array}{l}\text { International industry } \\
\text { partners }\end{array}$ & $\mathrm{I} 2$ & \\
\hline & Career prospects & I3 & \\
\hline \multirow[t]{3}{*}{ Access } & $\begin{array}{c}\text { Location of the } \\
\text { university }\end{array}$ & $\mathrm{S} 1$ & \multirow[t]{3}{*}{ [7], [12] } \\
\hline & Fees of the program & S2 & \\
\hline & Transportation links & S3 & \\
\hline
\end{tabular}

Reputation is described the higher educational image. Reputation of university (R1) is identified as the image of university that has been formed in Indonesian society. Accreditation of university (R2) is the formal recognition from accreditation entity against the universities competency and quality. National ranking (R3) and international ranking (R4) are the achievement of university assessed in both national and international scope. Prestige of the university (R5) has the similar meaning with R1. Information in mass media (R6) is identified as the existence of university on television, newspaper, magazines or another online mass media. While, alumni recommendation (R7) is the ability of alumni to compete in builing their career path and research quality (R8) is the number of indexed research that conducted by the university.

Industry linkage is decribes the career opportunity of students. National industry partners (I1) and international industry partners (I2) are the number of stakeholders from industries or companies owned by the university. Career prospects (I3) are the amount of opportunity for students to get jobs after they finish their study.

Access is related to the approachability of university. Location of the university (S1) is defined as how strategic the university located geographically. Fees of the program 
(S2) is the the cost that have to paid by students to finish their study at the university. Transportation links (S3) is defined as the ease of getting public transportation to go to the university.

Table 2. Approval score of constructs.

\begin{tabular}{|c|c|}
\hline Constructs & Approval score \\
\hline Academics & 1.00 \\
\hline Facilities & 1.00 \\
\hline Campus life & 1.00 \\
\hline Reputation & 1.00 \\
\hline Industry linkage & 1.00 \\
\hline Access & 1.00 \\
\hline
\end{tabular}

Table 3. Approval score of items.

\begin{tabular}{|c|c|}
\hline Items & Approval score \\
\hline $\mathrm{A} 1$ & 1.00 \\
\hline $\mathrm{A} 2$ & 1.00 \\
\hline $\mathrm{A} 3$ & 1.00 \\
\hline $\mathrm{A} 4$ & 1.00 \\
\hline $\mathrm{F} 1$ & 1.00 \\
\hline $\mathrm{F} 2$ & 1.00 \\
\hline $\mathrm{F} 3$ & 1.00 \\
\hline $\mathrm{F} 4$ & 1.00 \\
\hline $\mathrm{F} 5$ & 1.00 \\
\hline $\mathrm{C} 1$ & 1.00 \\
\hline $\mathrm{C} 2$ & 1.00 \\
\hline $\mathrm{C} 3$ & 1.00 \\
\hline $\mathrm{C} 4$ & 1.00 \\
\hline $\mathrm{C} 5$ & 0.25 \\
\hline
\end{tabular}

\begin{tabular}{|c|c|}
\hline Items & Approval score \\
\hline $\mathrm{R} 1$ & 1.00 \\
\hline $\mathrm{R} 2$ & 1.00 \\
\hline $\mathrm{R} 3$ & 1.00 \\
\hline $\mathrm{R} 4$ & 0.25 \\
\hline $\mathrm{R} 5$ & 0.25 \\
\hline $\mathrm{R} 6$ & 1.00 \\
\hline $\mathrm{R} 7$ & 1.00 \\
\hline $\mathrm{R} 8$ & 0.00 \\
\hline $\mathrm{I} 1$ & 1.00 \\
\hline $\mathrm{I} 2$ & 0.25 \\
\hline $\mathrm{I} 3$ & 1.00 \\
\hline $\mathrm{S} 1$ & 1.00 \\
\hline $\mathrm{S} 2$ & 1.00 \\
\hline $\mathrm{S} 3$ & 1.00 \\
\hline
\end{tabular}

\subsection{Content validity}

Content validity shows how representative and comprehensive the variables were. Table 2 and 3 presents the approval scores for 28 items being proposed. Variables whose approval scores were lower than 0.5 will be dropped from further analysis [11]. It can be inferred that there are five items dropped with approval scores 0.25 (C5), 0.25 (R4), 0.25 (R5), 0.00 (R8) and 0.25 (I2).

The experts argued that students won't regard that variables at the time they choosing university. The internship programmes (C5) and research quality (R8)

Table 4. Validity and reliability statistics.

\begin{tabular}{|c|c|c|c|}
\hline Cronbach's $\alpha$ & $\begin{array}{l}\text { Number } \\
\text { of items }\end{array}$ & Items & $\begin{array}{c}\text { Total } \\
\text { Correlation }\end{array}$ \\
\hline \multirow[t]{4}{*}{0.758} & \multirow[t]{4}{*}{4} & A1 & 0.553 \\
\hline & & $\mathrm{A} 2$ & 0.534 \\
\hline & & $\mathrm{A} 3$ & 0.604 \\
\hline & & A4 & 0.557 \\
\hline \multirow[t]{5}{*}{0.874} & \multirow[t]{5}{*}{5} & $\mathrm{~F} 1$ & 0.698 \\
\hline & & $\mathrm{F} 2$ & 0.869 \\
\hline & & F3 & 0.782 \\
\hline & & F4 & 0.646 \\
\hline & & F5 & 0.572 \\
\hline \multirow[t]{4}{*}{0.835} & \multirow[t]{4}{*}{4} & $\mathrm{C} 1$ & 0.662 \\
\hline & & $\mathrm{C} 2$ & 0.680 \\
\hline & & $\mathrm{C} 3$ & 0.711 \\
\hline & & $\mathrm{C} 4$ & 0.613 \\
\hline \multirow[t]{5}{*}{0.916} & \multirow[t]{5}{*}{5} & $\mathrm{R} 1$ & 0.840 \\
\hline & & $\mathrm{R} 2$ & 0.835 \\
\hline & & $\mathrm{R} 3$ & 0.769 \\
\hline & & R6 & 0.691 \\
\hline & & R7 & 0.860 \\
\hline \multirow[t]{2}{*}{0.693} & \multirow[t]{2}{*}{2} & I1 & 0.549 \\
\hline & & I3 & 0.549 \\
\hline \multirow[t]{3}{*}{0.808} & \multirow[t]{3}{*}{3} & $\mathrm{~S} 1$ & 0.747 \\
\hline & & S2 & 0.577 \\
\hline & & S3 & 0.664 \\
\hline
\end{tabular}

were dropped because that variables were the part of during course touchpoints, it means that the students will realize it by the time they studied there. International ranking of university (R4) was dropped because it only would be regarded if the students want to continue their 
study at an International University, while prestige of university (R5) was dropped because it has the same meaning with variable R1. Also, the international industry partners (I2) was dropped regarding the high competition among national industry in Indonesia.

\subsection{Construct validity and reliability}

Validity of the items depends on the sample size [13]. For a sample size of 50, a corrected item-total correlation more than 0.279 is considered valid. While the reliability figured from the Cronbach's $\alpha$ with the lowest acceptable limit is 0.6 [14]. Table 4 shows the results of validity and reliability test using SPSS 16.0.

Total correlation for all items were greater than 0.5 , indicating good discriminant validity to describe the real situation of this research.

The two items of industry linkage have a moderate reliability with Cronbach's $\alpha 0.693$. The 21 items of academics, facilities, campus life, reputation and access have a high reliability with Cronbach's $\alpha 0.758,0.874$, $0.835,0.916$ and 0.808 . It shows that the respondent's answers were reliable to uncover the research objective.

\section{Conclusion}

This study identifies the factors influencing the student's decision to continue their study at higher education. It shown that there are 6 factors that affecting the choice of university, including academics, facilities, campus life, reputation, industry linkage and access. From 28 items proposed, there are five items dropped from further analysis and resulting 23 significant items that can be considered as important aspects of choosing universities.

This findings shows that university experience is now concerned by students besides the skills and ability of their graduates. It provides a guidance for State University in developing their marketing strategies.

This research was partially funded by Diponegoro University in "Penelitian Dasar Department of Industrial Engineering" Program.

\section{References}

1. A. Firdaus, Int. J. Cons. Stud. 30, 6, 569-581 (2006)

2. R. East, Prentice Hall. (1997)

3. S. Munisamy, N. I. M. Jaafar, S. Nagaraj, Asia-Pac. Educ. Res. 23, 3, 451-462 (2014)

4. J. H. Brown, T. Melewar, B. Nguyen, E. Wilson, J. Bus. Res. 69, 8, 3019-3022 (2016)

5. L. Galloway, TQM Mag. 10, 1, 20-26 (1998)

6. C. Dennis, S. Papagiannidis, E. Alamanos, M. Bourlakis, J. Bus. Res. 69, 8, 3049-3057 (2016)

7. M. Khanna, I. Jacob, N. Yadav, J. Mark. High. Educ. 24, 1, 122-143 (2014)

8. D. Hossler, K.S. Gallagher, Coll. Univ. 62, 3, 207221 (1987)

9. T. Gatfield, M. Barker, P. Graham, Corp. Comm. Int. J. 4, 2, 73-79 (1999)

10. C. Plewa, J. Ho, J. Conduit, I. O. Karpen, J. Bus. Res. 69, 8, 3087-3095 (2016)

11. K. Williamson, Chandos Publishing. (2002)

12. T. Woodall, A. Hiller, S. Resnick, Stud. High. Educ. 39, 1, 48-67 (2014)

13. A. Field, SAGE Publications. (2009)

14. J. F. Hair, R. E. Anderson, R. L. Tatham, W. C. Black, Prentice Hall. (1998) 